\title{
Evaluation and Development of Pedotransfer Functions for Estimating Soil Water Holding Capacity in the Tropics: The Case of Sokoine University of Agriculture Farm in Morogoro, Tanzania
}

\author{
Makarius V. Mdemu ${ }^{1}$ \\ ${ }^{1}$ Department of Regional Development Planning, Ardhi University, Tanzania \\ Correspondence: Makarius V. Mdemu, Department of Regional Development Planning, Ardhi University, \\ Tanzania. Tel: 255-765466058. E-mail:mak_mdemu@yahoo.co.uk
}

Received: December 17, 2014 Accepted: January 14, 2015 Online Published: January 23, 2015

doi:10.5539/jgg.v7n1p1 URL: http://dx.doi.org/10.5539/jgg.v7n1p1

\begin{abstract}
Direct field measurements of soil hydraulic parameters including the soil moisture retention are fraught with technical difficulties, making use of Pedo transfer functions key for their estimation. The PTFs of Tomasella and Hodnett were evaluated for their applicability to estimate soil water retention capacity at matric potentials of 1 , 10, 33, 100, $1500 \mathrm{kPa}$ using soil texture and organic carbon measured from the Sokoine University of Agriculture (SUA) farm. The Tomasella and Hodnett PTFs underestimated moisture retention at 1 and $1500 \mathrm{kPa}$ matric potentials while it overestimated the moisture retention at 10,33 and $100 \mathrm{kPa}$. New multiple linear regressions for the estimation of soil moisture retention were derived using percentage silt and clay, organic carbon and bulk density and moisture retention at 1, 10,33, 100 and 1500kPa measured from the SUA farm. In the newly developed PTFs, percentage clay and organic carbon explained well soil moisture retention at $0.1 \mathrm{kPa}$ and AWC while moisture retention at other matric potentials could be well explained by percentage clay, organic carbon and bulk density. The evaluated PTFs of Tomasella and Hodnett produced reliable estimates of soil moisture retention at $33 \mathrm{kPa}$ and $1500 \mathrm{kPa}$. However, the PTFs derived from locally measured soils improved the efficiency of soil moisture retention prediction with all used physicochemical properties significantly contributing to soil moisture retention at different matric potentials.
\end{abstract}

Keywords: Pedo-transfer functions, soil moisture retention, matric potentials, multiple linear regressions

\section{Introduction}

Soil water holding capacity is one of the key parameters important in soil and water management practices for sustainable and improved agricultural production (Obalum and Obi, 2012). The parameter is important for both modeling the hydrology of segments of the landscape and for evaluating field soil water regimes in relation to the potential of soil for various uses (Wösten, et al., 2013). Functional application of soil hydraulic properties have included modeling the hazard of ponding, runoff and erosion and the potential of a soil for tile drainage, septic filter fields, production of certain crops and other uses (Mdemu \& Mlengera, 2002). Soil hydraulic parameters are also important in determining infiltration, irrigation practice, drainage design, runoff, ground water recharge and in simulating leaching and other agricultural and hydrological processes (Jabro, 1992).

Although soil hydraulic parameters are increasingly needed for various applications, they are not routinely determined by soil surveyors partly because of the difficulties to measure them (Tietje \& Hennings, 1996). Direct measurements of soil water retention capacity are expensive, time consuming and labour intensive (Obalum \& Obi, 2012; Wösten, et al., 2013). However, the parameters can alternatively be estimated using available soil data such as particle size distribution, organic matter content, bulk density and soil porosity (Schaap et al., 1999; Young et al., 1999). The methods or equations used to estimate soil water retention capacity from available soil data are called pedo-transfer functions (PTFs) (Wösten, et al., 2013; Keshavarzi et al., 2011; Young et al., 1999). The regression equations that either directly or indirectly relate readily available, easily measured soil physical and chemical data to soil hydraulic properties is one of the key forms of pedotransfer functions. These functions serve to translate the basic information found in the soil survey into a form useful for broader applications, such as simulation modelling (Wagenet et al., 1991).

The major work in the development of PTFs has been in the temperate regions (Young et al., 1999). Significant 
variations in soil physical, biological and chemical properties, which are the key parameters for PTFs, between the tropical and temperate is a major barrier in applicability of the existing pedo transfer functions in tropical regions including Sub-Saharan Africa (Wösten, et al., 2013; Gowing \& Young, 1996; Young et al., 1999). This study aimed at: i) assessing the possibility of using a pedotransfer functions developed from the Brazilian tropical soils for estimating the water holding capacity under Tanzanian soil conditions; and ii) developing new pedotransfer functions for estimating soil moisture retention based on locally measured soil physicochemical properties.

\section{Method}

The study was conducted on the central and North West parts which covers approximately 422.5 ha of the Sokoine University of Agriculture (SUA) farm in Morogoro, Tanzania. The area is characterised by semi-humid tropical climate with bimodal rainfall pattern (November - January and March -May) and a warm temperature (average $24^{\circ} \mathrm{C}$ ) throughout the year. The study area consists of soils that are derived from colluvium material of the Uluguru Mountains. Nitisols, Luvisols and Ferralsols are the main soil types found in the study area. Large part of the farm is used for long term fallow while other areas are used for seasonal cultivation of cereal crops.

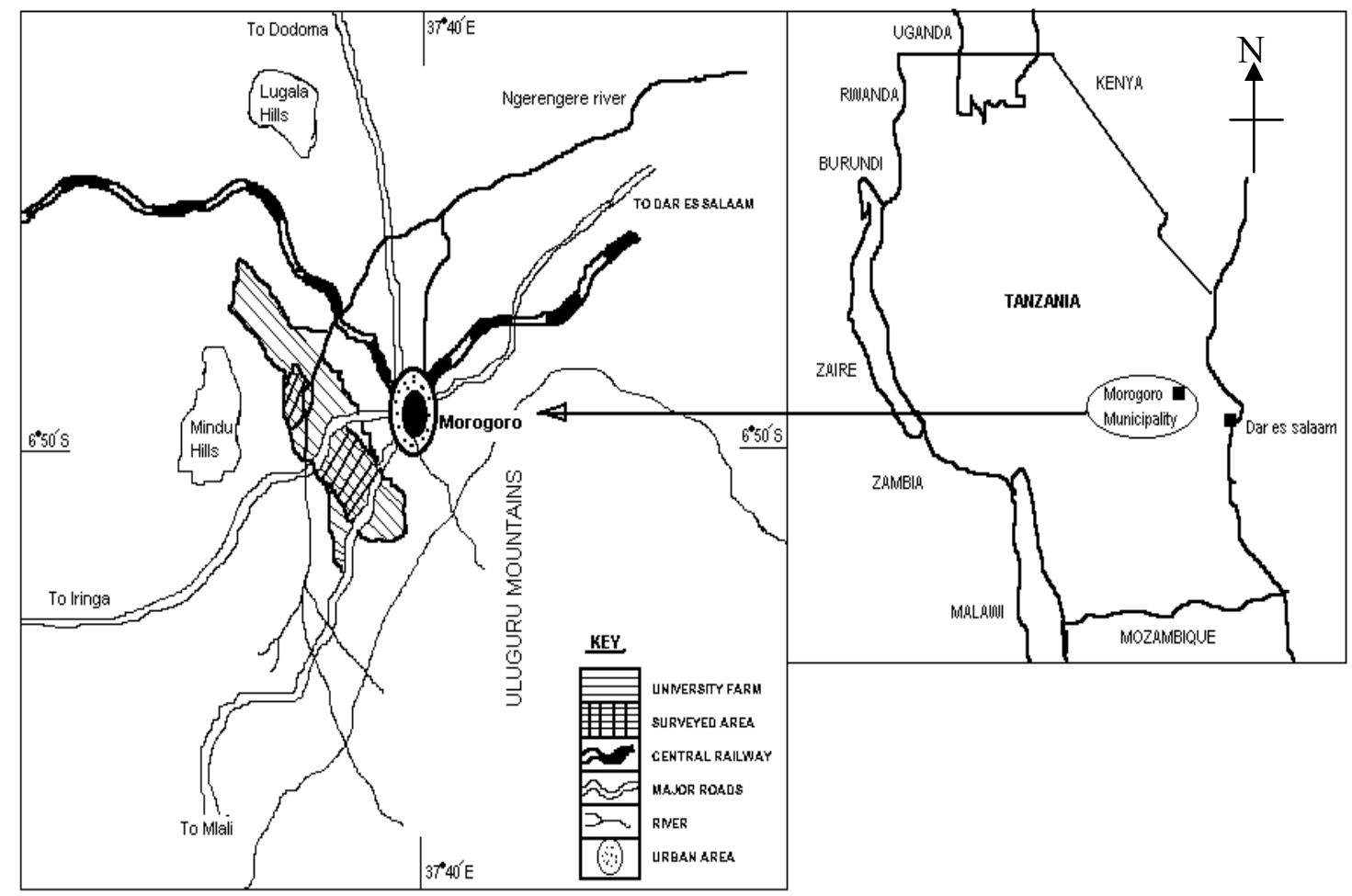

Figure 1. Location of the study area -longitude $37^{\circ} 39^{\prime} \mathrm{E}$ and latitude 6050'S (Source: Mdemu, 2002)

A total of 14 profiles located on soils ranging from clays to sands were dug. Fifty one bulk soil samples were collected from different horizons of the soil profiles and 3 undisturbed core samples were also collected from every horizon (Blake \& Hartge 1986). Disturbed soil samples were analysed for soil texture fractions and organic carbon. Soil texture was determined using hydrometer method (Day, 1965). Organic carbon was determined by wet oxidation method of Walkley and Black (Nelson and Sommers, 1996). Particle density was assumed to be equal to $2.65 \mathrm{~g} / \mathrm{cm}^{3}$, a commonly used value for agricultural soils. Soil porosity was calculated from the determined bulk density and particle density (Landon, 1991).

Two of the three core samples from each horizon were used to determine soil water retention characteristics (SWRCs). The SWRCs were determined using pressure membrane apparatus for suctions of $0.1,1,10$, and 33 $\mathrm{kPa}$. The same samples used on the pressure membrane apparatus were transferred to the pressure plate apparatus for determining the SWRCs for suctions of 50,100, and $1500 \mathrm{kPa}$. Soil water retention at 33 and 1,500 $\mathrm{kPa}$ were taken to represent field capacity (FC) and permanent wilting point (PWP) water contents. The available water capacity (AWC) was determined as the difference between FC and PWP water contents. The samples used to determine the SWRCs together with the third sample from each horizon were used to determine bulk density after oven drying at $105^{\circ} \mathrm{C}$ (Blake \& Hartge 1986). 
Pedotransfer Function (PTFs) developed by Tomasella and Hodnett (1998) in Brazili (Regression Models 1 to 5 in Table 1) for estimating soil moisture retention capacity were evaluated for their ability to estimate soil water retention capacity based on soil texture ( $\%$ silt and clay) data determined from the SUA farm.

Table 1. Multiple linear regressions of Tomasella and Hodnett (1998) for the prediction of volumetric water content as a function of percentage silt and clay at different matric potentials

\begin{tabular}{llccccc}
\hline Regression Model & $\Phi_{\mathrm{m}}(\mathrm{kPa})$ & Intercept & Silt \% & Clay \% & No. of data points & $\mathrm{R}$ \\
\hline 1 & 1 & 23.839 & $0.530(0.018)$ & $0.225(0.019)$ & 196 & 0.902 \\
2 & 10 & 9.806 & $0.543(0.016)$ & $0.321(0.015)$ & 234 & 0.918 \\
3 & 33 & 4.046 & $0.426(0.015)$ & $0.404(0.012)$ & 416 & 0.882 \\
4 & 100 & 3.198 & $0.369(0.015)$ & $0.351(0.015)$ & 196 & 0.897 \\
5 & 1500 & 0.910 & $0.150(0.013)$ & $0.396(0.010)$ & 416 & 0.889 \\
\hline
\end{tabular}

$\Phi_{\mathrm{m}}$ stands for matric potential and R stands for correlation coefficient. Values in brackets are standard error.

Determined values of percentage silt and clay were inserted into models 1-5 in Table 1 above to estimate the soil moisture retention at the matric potentials of $1,10,33,100,1500 \mathrm{kPa}$ respectively and at AWC. Results of estimated soil moisture retention by the PTFs were compared with measured values using scatter plots and determined mean differences (MD), root of mean squared differences (RMSD) and the correlation coefficients (R). New PTFs were then developed using soil physicochemical properties (mainly textural fraction of silt and clay, organic carbon and bulk density) measured from the farm.

\section{Results}

\subsection{Evaluation of Tomasella and Hodnett PTFs for Soil Moisture Retention}

The average volumetric soil moisture retention estimated by Tomasella and Hodnett PTFs were 37.07, 27.38, 24.60, 21.05, 19.42 and 5.15 vol.vol-1\% at the matric potentials of 1, 10, 33, 100, $1500 \mathrm{kPa}$ and AWC respectively (Table 2). Retained moisture content showed a decreasing trend with the decrease in matric potentials. Overall, there was good estimate of soil moisture retention capacity at field capacity (FC) (33 kPa) and permanent wilting point $(1500 \mathrm{kPa})$ (Figure 2) by the tested PTFs. The PTFs overestimated soil moisture retention at matric potentials of 1 and $1500 \mathrm{kPa}$ while it underestimated the moisture content at the matric potentials of $10 \mathrm{kPa}, 100 \mathrm{kPa}$ and the available water capacity.

Table 2. Tomasella and Hodnett PTFs predicted and measured soil moisture retention capacity at determined matric potentials

\begin{tabular}{lrrrccc}
\hline \multirow{2}{*}{$\begin{array}{l}\text { Matric } \\
\text { potential (kPa) }\end{array}$} & \multicolumn{3}{c}{$\begin{array}{c}\text { Predicted soil moisture retention \% } \\
\text { (vol.vol-1\%) }\end{array}$} & \multicolumn{3}{c}{$\begin{array}{c}\text { Measured soil moisture retention \% } \\
\text { (vol.vol-1\%) }\end{array}$} \\
\cline { 2 - 7 } & Minimum & Maximum & Average & Minimum & Maximum & Average \\
\hline 1 & 25.35 & 45.51 & 37.07 & 10.91 & 47.93 & 31.76 \\
10 & 11.53 & 38.55 & 27.38 & 8.33 & 46.00 & 29.06 \\
33 & 5.71 & 38.16 & 24.60 & 6.84 & 43.61 & 25.76 \\
100 & 4.64 & 32.83 & 21.05 & 5.07 & 39.30 & 23.09 \\
1500 & 2.00 & 32.21 & 19.42 & 1.37 & 31.55 & 18.52 \\
AWC & 3.70 & 7.76 & 5.17 & 2.14 & 23.30 & 7.20 \\
\hline
\end{tabular}


A

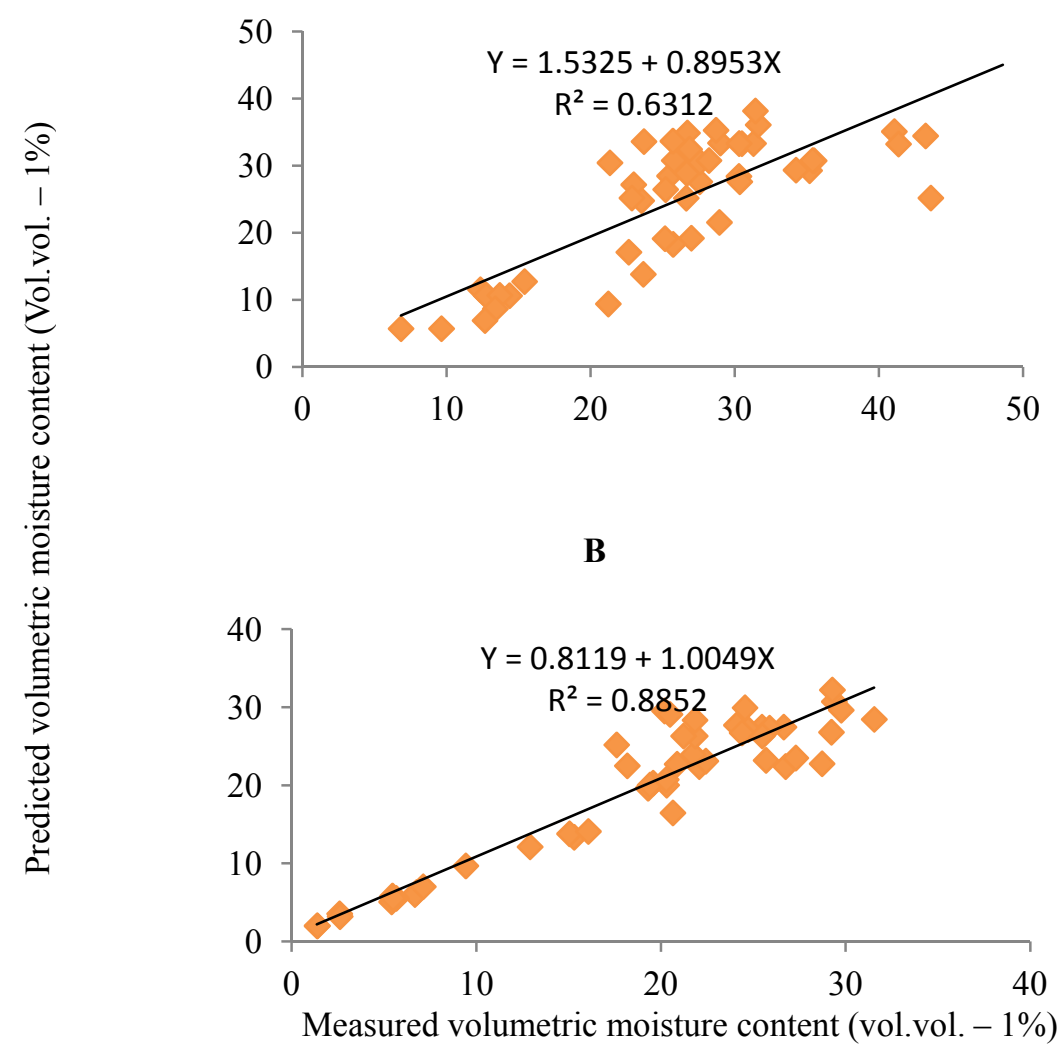

Figure 2. The relationships between moisture contents predicted (Y) using Tomasella and Hodnett (1998) PTFs and measured values $(\mathrm{X})$ at FC (A) and PWP (B)

The correlation coefficients between measured and estimated soil moisture retention capacity were good except for AWC, which recorded a very small and negative correlation coefficient (Table 3). Low correlation could have been influenced by determination of AWC as a difference between FC and PWP. The estimated soil water content by Tomasella and Hodnett PTFs increased with increase in percentage clay. No variation of soil water content was observed with the increase or decrease in percentage silt content. This was probably due to low content of silt fractions in the soils.

Table 3. Performance comparison between the measured soil water contents from the farm and those predicted by Tomasella and Hodnett PTFs

\begin{tabular}{cccc}
\hline $\begin{array}{c}\text { Matric potentials } \\
(\mathrm{kPa})\end{array}$ & $\begin{array}{c}\text { MD } \\
(\text { vol.vol-1\%) }\end{array}$ & $\begin{array}{c}\text { RMSD } \\
\text { (vol.vol-1\%) }\end{array}$ & $\mathrm{R}$ \\
\hline 1 & -0.05 & 0.07 & 0.83 \\
10 & 0.02 & 0.05 & 0.82 \\
33 & 0.02 & 0.06 & 0.79 \\
100 & 0.02 & 0.05 & 0.81 \\
1500 & -0.01 & 0.04 & 0.94 \\
AWC & 0.02 & 0.05 & -0.11 \\
Mean & 0.002 & 0.054 & 0.68 \\
\hline
\end{tabular}

MD stands for mean difference, RMSD stands for root mean squared difference, $\mathrm{R}$ stands for correlation coefficient and AWC stands for available water capacity.

The difference between estimated and measured water contents was influenced by differences in soil texture fractions (\% clay, silt) used in developing the Tomasella and Hodnett PTFs from those determined at SUA farm and applied in evaluating the PTFs. The Tomasella and Hodnett PTFs were developed using only soil texture (\% clay and silt) which might have impaired the predictive capacity of the models. Soil physical properties such as 
bulk density and soil organic carbon that have influence on soil water retention were not included due to inconsistency of the properties from the data points used in developing the models (Tomasella and Hodnett, 1998). Generally good estimates of soil moisture retention capacity were obtained at the respective matric potentials considering the little soil information used in the development of evaluated Tomasella and Hodnett PTFs. This suggests the potential of PTFs that have been developed from tropical soils for estimating the moisture retention for soils from tropical areas.

\subsection{Locally Developed PTFs for Soil Water Retention Capacity}

New regression equations (PTFs) for estimating soil moisture retention at different matric potentials were developed based on the relationship between the matric potentials and physicochemical properties of soils (clay, silt, bulk density and organic carbon) (Table 4). Results showed that clay and organic carbon could explain well the soil moisture retention at $0.1 \mathrm{kPa}$ and AWC. Soil moisture retentions at other matric potentials were explained well by percentage clay, organic carbon and bulk density. The contribution of percentage silt was not significant for most developed equations except for the soil moisture retention at Permanent Wilting Point (1500 kPa). This was primarily due to low content of silt in the soils (1-15\%).

Table 4. Coefficients of multiple linear regression equations developed for predicting volumetric water content using soil physicochemical properties from SUA farm

\begin{tabular}{cccccccc}
\hline $\begin{array}{c}\text { Regres } \\
\text { sion } \\
\text { Model }\end{array}$ & $\begin{array}{c}\text { Matric } \\
\text { potential } \\
(\mathrm{kPa})\end{array}$ & Intercept & Clay, \% & Silt, \% & OC, $\%$ & BD $\left(\mathrm{g} / \mathrm{cm}^{3}\right)$ & $\mathrm{R}$ \\
\hline 1 & 0.1 & 35.22 & $0.10(0.025)$ & & $3.09(1.028)$ & & 0.66 \\
2 & 1 & 16.19 & $0.27(0.027)$ & $5.03(1.120)$ & & 0.89 \\
3 & 10 & -4.37 & $0.32(0.037)$ & $5.16(1.139)$ & $11.84(5.335)$ & 0.89 \\
4 & 20 & -8.76 & $0.32(0.036)$ & $5.36(1.132)$ & $13.59(5.304)$ & 0.88 \\
5 & 33 & -12.33 & $0.31(0.036)$ & & $5.52(1.120)$ & $15.33(5.249)$ & 0.88 \\
6 & 50 & -12.62 & $0.31(0.035)$ & & $5.37(1.099)$ & $15.06(5.150)$ & 0.89 \\
7 & 100 & -13.35 & $0.31(0.034)$ & & $5.01(1.069)$ & $14.38(5.010)$ & 0.89 \\
8 & 1500 & -23.60 & $0.41(0.019)$ & $0.03(0.129)$ & $1.25(0.651)$ & $16.15(2.833)$ & 0.97 \\
9 & AWC & 8.75 & $-0.090 .021)$ & & $3.59(0.891)$ & & 0.60 \\
\hline
\end{tabular}

$\mathrm{OC}$ stands for organic carbon and BD stands for bulk density. Values in brackets are standard error.

The percentage sand and total porosity were not included in the multiple linear regression equations developed using soils from SUA farm in order to avoid multicolinearity effects. All the physicochemical properties were tested for multicolinearity effects and it was found that these two parameters exhibited colinearity effects with silt, clay and bulk density. The main reason of multicolinearity was due to the fact that sand is a linear combination of clay and silt, and total porosity is derived from bulk and particle densities. Use of either sand or porosity in developing regression equations could have yielded similar results as to when clay and bulk density have been used in the development of linear multiple regression equations. No multicollinearity and correlation between percentage silt and organic carbon was observed.

Results showed existence of a good relationship between the measured and estimated water content at $33 \mathrm{kPa}$ and $1500 \mathrm{kPa}$ by the developed regression equations. The points of measured and predicted soil water contents lay consistently above or below a linear fitted line indicating a good agreement between the measured and estimated water content (Figure 3). The regression equation for estimating AWC tended to overestimate the water contents. Overall, the water contents were overestimated by $52 \%$ and underestimated by $48 \%$ from the developed multiple regression equations. The retained soil moisture at selected matric potentials increased with the increase in clay content, soil organic carbon and bulk density. 


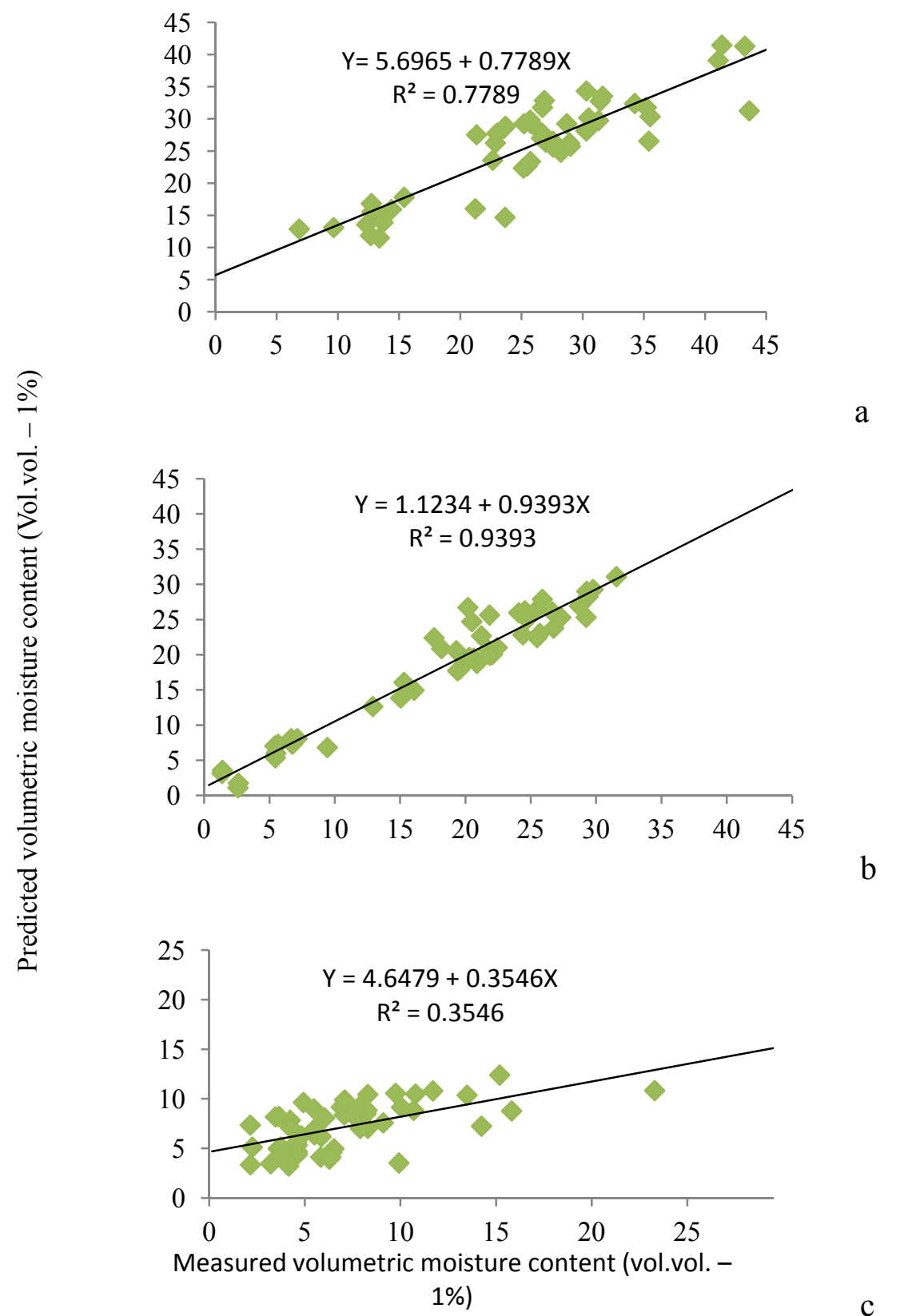

Figure 3. The relationships between moisture contents predicted (Y) using developed PTFs and measured values (X) at matric potentials of the models of $33 \mathrm{kPa}(\mathrm{a}), 1500 \mathrm{kPa}(\mathrm{b})$ and $\mathrm{AWC}(\mathrm{c})$

\section{Discussion}

The soil moisture retention at different matric suctions increased with increasing clay content. Clay soils can hold a significant amount of water because of the relatively large surface areas of individual clay particles and the large number of small pores. Clay acts as a binding agent between soil particles and it gives soil elasticity and provides cohesion of soil particles resulting into a network of capillary pores that hold moisture against the force of gravity (Bruand \& Tessier, 2010). The percentage clay explained more than $60 \%$ of soil moisture retention at all matric potentials except for matric potential of $0.1 \mathrm{kPa}$. Clay content significantly $(\mathrm{p}<0.05)$ contributed to the soil moisture retention of all the developed regression equations at the respective matric potentials.

The percentage $\mathrm{OC}$ also significantly $(\mathrm{p} \leq 0.04)$ contributed to the developed soil moisture retention regression equations for all the matric potentials except at PWP while the BD showed insignificant contribution at the 
matric potentials of $0.1,1 \mathrm{kPa}$ and at $\mathrm{AWC}$. As result, $\mathrm{BD}$ could not be included in the regression equation for the respective matric potentials. Addition of $\mathrm{OC}$ to the independent variables of the regression equations increased the coefficient of determination to more than $70 \%$ in all soil moisture retention except for soil moisture retention at $1 \mathrm{kPa}$. The soil water content retention capacity for the top soils was more a characteristic of OC than clay because percentage clay for the topsoil was relatively low than percentage clay of the sub-soil. According to Kay et al. (1997) an increase in the OC content of $0.01 \mathrm{~kg} / \mathrm{kg}$ may contribute to increases in available water content from 0.02 to 0.04 vol.vol- $1 \%$ with the largest increase occurring in coarser-textured soils. This increase in water content may also be associated with decrease of the air-filled porosity at field capacity from 0.01 to 0.04 vol.vol- $1 \%$ with the largest decreases occurring on finer textured soils. The effect of OC on water retention, especially at low matric potentials, has been recognized by several authors (Mandal et al., 2013, Saxton and Rawls, 2006; Rawls et al., 2003). However, other studies (e.g., Van den Berg et al., 1997) have portrayed a contradictory role of $\mathrm{OC}$ in soil moisture retention capacity. Low $\mathrm{OC}$ content of highly weathered and well drained soils may negatively influence the soil moisture retention capacity. In spite of low levels of OC of soils from the SUA farm, organic carbon was one of the important parameters in explaining the soil moisture retention patterns at different matric potentials.

Decrease in BD at all matric potentials correlated with increase in soil moisture retention capacity despite the fact that BD positively correlated with soil water retention for developed PTFs from 10kPa to PWP. However, soils with low bulk densities retain more water than soils with a higher bulk density (van den Berg et al., 1997). High BD is associated with low number of water filled pores. The amount of water that can be retained at a given suction also depends primarily on the available pore space among other factors and, therefore, soils with low BDs are generally considered to be better structured, having sufficient amount of pore spaces than soils with high BD (Dec et al., 2008; Saxton \& Rawls, 2006; van den Berg et al., 1997).

Estimate of AWC was inferior when compared to estimated soil moisture retention at different matric potentials. Batjes (1996) and van den Berg et al. (1997) suggested that predicting AWC is most accurate when a direct correlation is made between the differences in measured moisture content at FC and PWP and easily measured soil physicochemical properties. However, no improvements could be realized in estimates of AWC based on direct correlation between the differences of measured moisture content at FC and PWP and the soil physicochemical properties. Lack of improved estimates was influenced by determining AWC as a difference between FC and PWP. The efficiency of prediction of soil moisture retention by the regression equations developed from the measured physicochemical properties at SUA farm increased with the increase in matric potential (Table 5). Reliable estimate of soil MRC was obtained at $1500 \mathrm{kPa}$ matric potential as reflected by high correlation coefficient. A number of findings (Vereecken, 1995 \& 1988; Vereecken et al., 1992) suggest that the use of measured soil moisture at FC and PWP among the independent variables can increase estimates of moisture retention capacity of soils at different matric potentials. In this study, attempt was not made to include FC and PWP in the soil moisture descriptor variables because the estimated soil moisture retention using physicochemical properties were of reasonable and reliable accuracy.

Table 5. Performance comparison between the measured soil water contents from the farm and those predicted by the developed PTFs

\begin{tabular}{cccc}
\hline Matric Potential $(\mathrm{kPa})$ & MD & RMSD & $\mathrm{R}$ \\
\hline 0.1 & -0.06 & 0.07 & 0.66 \\
1 & -0.06 & 0.07 & 0.83 \\
10 & 0.02 & 0.05 & 0.89 \\
20 & 0.02 & 0.06 & 0.88 \\
33 & 0.02 & 0.06 & 0.88 \\
50 & 0.02 & 0.06 & 0.89 \\
100 & 0.02 & 0.05 & 0.89 \\
1500 & 0.01 & 0.03 & 0.97 \\
AWC & 0.01 & 0.04 & 0.60 \\
Mean & 0.001 & 0.06 & 0.83 \\
\hline
\end{tabular}

MD stands for mean difference, RMSD stands for root mean squared difference, $\mathrm{R}$ stands for correlation coefficient, AWC stands for available water capacity (vol.vol-\%).

A good agreement between the measured and predicted soil water contents at the selected matric potentials was 
obtained in this study. The soil physicochemical variables used in developing the PTFs for predicting the soil moisture retention contributed significantly $(\mathrm{p}<0.05)$ to the predicted soil moisture retention at different matric potentials. The insignificant contribution of OC at PWP was translated to reflect the influence of soil texture on soil moisture retention at lower matric potentials than other properties. Overall, water contents estimated using developed PTFs was close to the measured water contents as reflected by small mean differences and high correlation coefficients between the measured and predicted soil moisture retention. The high correlation coefficients of developed PTFs guarantee usability of these PTFs for estimating soil moisture retention for soils with similar physiochemical properties to those found at SUA Farm.

\section{Conclusions}

The evaluated PTF of Tomasella and Hodnett for water holding capacity produced reasonable prediction results of soil moisture retention at matric potentials greater than or equal to $33 \mathrm{kPa}$. The predicted soil moisture retention by the externally generated PTFs matched measured soil moisture contents well except for the moisture retention at available water capacity. PTFs derived from locally measured soils improved the efficiency of soil moisture retention prediction with all used physicochemical properties significantly contributing to soil moisture retention at the respective matric potentials.

\section{Acknowledgement}

The author acknowledges the financial support from SACCAR/GTZ to conduct the research work.

\section{References}

Batjes, N. H. (1996). Development of a World data set of soil water retention properties using pedotransfer rules. Geoderma, 71, 31-52. http://dx.doi.org/10.1016/0016-7061(95)00089-5

Berg, V. D., Klamt, M. E., \& Reeuwijk, L. P., \& Sombroek, W. G. (1997). Pedotransfer functions for the estimation of moisture retention characteristics of Ferralsols and related soils. Geoderma, 78, 161-180. http://dx.doi.org/10.1016/S0016-7061(97)00045-1

Blake, G. R., \& Hartge, K. H. (1986). Bulk density. In: Klute, A. et al. (eds.) Methods of Soil Analysis, Part 1. 2nd Edition. American Society of Agronomy, Inc. Soil Science Society of America, Monograph, 9, Madison, Wisconsin, USA, 363-375.

Bruand, A., \& Tessier, D. (2010). Water retention properties of the clay in soils developed on clayey sediments: signi_cance of parent material and soil history. European Journal of Soil Science, Wiley-Blackwell, 2000, 51, pp.679-688.

Day, P. R. (1965). Particle fractionation and particle size analysis. In Black, C. A., Evans, D. D., White, J. L., Ensmingere, L. E., \& Clark, F. E. (Eds.), Methods of Soil analysis part 1(pp. 545-566). American Society of Agronomy, Wisconsin.

Dec, D., Dorner, J., Becker, F. O., \& Horn, R. (2008). Effect of Bulk Density on Hydraulic Properties of Homogenized and Structured Soils, R. C. Suelo Nutr. Veg., 8(1), 1-13.

Gowing, J. W., \& Young, M. D. B. (1996). Evaluation and Promotion of Rainwater Harvesting in Semi-Arid Areas. Final Technical Report. University of Newcastle. p84.

Jabro, J. D. (1992). Estimation of saturated hydraulic conductivity of soils from particle size distribution and bulk density data. Transaction of the American Society of Agricultural Engineers, 35(2), 557-560. http://dx.doi.org/10.13031/2013.28633

Kay, B. D., Silva, A. P., \& Baldock, J. A. (1997). Sensitivity analysis of soil structure to changes in organic carbon content: Prediction using pedotransfer functions. Canadian Journal of Soil Science, 77(4), 655-667. http://dx.doi.org/10.4141/S96-094

Keshavarzi, A., Sarmadian, F., Labbafi, R., \& Ahmadi, A. (2011). Developing Pedotransfer Functions for Estimating Field Capacity and Permanent Wilting Point Using Fuzzy Table Look-up Scheme. Computer and Information Science, 4(1). http://dx.doi.org/10.5539/cis.v4n1p130

Landon, J. R. (1991). Booker Tropical Soil Manual: A handbook for soil survey and agricultural land evaluation in the tropics and subtropics. Longman Scientific and Technical Publishers. Essex, pp 474.

Mandal, K. G., Kundu, D. K., Singh, R., Kumar, A., Rout, R., Padhi, J., Majhi, P., \& Sahoo, D. K. (2013). Cropping practices, soil properties, pedotransfer functions and organic carbon storage at Kuanria canal command area in India, SpringerPlus, 2, 631. http://dx.doi.org/10.1186/2193-1801-2-631 
Mdemu, M. V. C. (2002). Evaluation of pedo-transfer functions for the estimation of hydraulic properties in some morogoro soils, Tanzania. Unpublished MSc Dissertation. Sokoine University of Agriculture, Morogoro, Tanzania

Mdemu, M. V., \& Mulengera, M. K. (2002). Using pedotransfer functions (PTFs) to estimate soil water retention characteristics (SWRCs) in the tropics for sustainable soil water management: Tanzania case study. Proceedings of the 12th ISCO Conference, II, 26-31 May, 2002, Beijing, China; 657-662.

Nelson, D. W., \& Sommers, L. E. (1996). Total nitrogen, organic carbon and organic matter. In Page, A. L. et al. (Eds.), Methods of Soil Analysis part 2 (pp. 539-579). Agronomy 9.

Obalum, S. E., \& Obi, M. E. (2012). Moisture characteristics and their point pedotransfer functions for coarse-textured tropical soils differing in structural degradation status. Hydrol. Process, 27, 2721-2735. http://dx.doi.org/10.1002/hyp.9398

Rawls, W. J., Pachepsky, Y. A., Ritchie, J. C., Sobecki T. M., \& Bloodworth, H. (2003). Effect of soil organic carbon on soil water retention. Geoderma, 116(1-2), 61-76. http://dx.doi.org/10.1016/S0016-7061(03)00094-6

Saxton, K. E., \& Rawls, W. J. (2006). Soil Water Characteristics Estimates by Texture and Organic Matter for Hydrological Solutions. Soil Sci. Soc. Am. J. 70, 1569-1578. Soil \& Water Management \& Conservation, Soil Physics. http://dx.doi.org/10.2136/sssaj2005.0117

Schaap, M. G., Leij, F. J., \& Genuchten, M. Th. (1999). Development of pedotransfer functions and related computer programs. U.S. Salinity Laboratory, Riverside, CA, pp 7.

Tietje, O., \& Hennings, V. (1996). Accuracy of the saturated hydraulic conductivity prediction by pedo-transfer functions compared to variability within FAO textural classes. Geoderma, 69, 71-84. http://dx.doi.org/10.1016/0016-7061(95)00050-X

Tomasella, J., \& Hodnett, M. G. (1998). Estimating soil water retention characteristics from limited data in Brazilian Amazonia. Soil Science, 163(3), 190-202. http://dx.doi.org/10.1097/00010694-199803000-00003

Vereecken, H. (1988). Pedotransfer functions for the Generation of Hydraulic Properties for Belgian Soils. PhD Thesis. K. U. Leuven, pp 254.

Vereecken, H. (1995). Estimating the unsaturated hydraulic conductivity from theoretical models using simple soil properties. Soil Science, 65, 81-92.

Vereecken, H., Diels, J., Orshoven, J. Feyen, J., \& Bouma, J. (1992). Functional evaluation of pedotransfer functions for the estimation of soil hydraulic properties. Soil Science Society of America Journal, 56, 1371-1378. http://dx.doi.org/10.2136/sssaj1992.03615995005600050007x

Wagenet, R. J., Bouma, J., \& Grossman, R. B. (1991). Minimum data sets for use of soil survey information in soil interpretive models. In Mausbach M. J., \& Wilding L. P. (Eds.), Spatial variabilities of soils and Landforms. Soil Science Society of America Special Publication No. 28, Madsons, WI.

Wösten, J. H. M., Verzandvoort, S. J. E., Leenaars, J. G. B., Hoogland, T., \& Wesseling, J. G. (2013). Soil hydraulic information for river basin studies in semi-arid regions. Geoderma, 195-196, 79-86. http://dx.doi.org/10.1016/j.geoderma.2012.11.021

Young, M. D. B., Gowing, J. W., Hatibu, N., Mahoo, H. M. F., \& Payton, R. W. (1999). Assessment and development of pedotransfer functions for Semi-Arid Sub-Saharan Africa. Physics and Chemistry of the Earth -European Geophysical Society (B), Elsevier Science Ltd. 24, 845-849. http://dx.doi.org/10.1016/S1464-1909(99)00091-X

\section{Copyrights}

Copyright for this article is retained by the author(s), with first publication rights granted to the journal.

This is an open-access article distributed under the terms and conditions of the Creative Commons Attribution license (http://creativecommons.org/licenses/by/3.0/). 